\title{
Merengue Típico in New York City: A History
}

\author{
SYDNEY HUTCHINSON
}

\section{ABSTRACT}

A transnational music scene has developed since the 1960s connecting New York City with Santiago, Dominican Republic, through merengue típico, or traditional, accordion-based merengue (also termed perico ripiao). New York-based musicians and fans have transformed the musical, social, and economic practices of tipico in both locations by incorporating influences from hip-hop, reggaetón, rock, house, and other forms of internationally popular music, while bringing the style to new audiences through both radio and live performance. This article traces the history of merengue tipico in New York City through the testimony of tipico musicians and producers. In doing so, it demonstrates that Dominican Americans and transnational migrants have been important players in the development of this musical genre for nearly half a century, particularly in the modern style termed merengue con mambo. While this style is controversial precisely because of the traces of transnational encounters it shows, which cause traditionalists to fear for the music's future, típico's capacity for change in fact serves to ensure its continued relevance for new generations.

Keywords: Dominican Americans, traditional music, urbanization, merengue, accordion, fusion, transnationalism, migration, perico ripiao, Cibao, New York City.

Sydney Hutchinson is an Assistant Professor of Ethnomusicology in the Department of Art and Music Histories at Syracuse University.

Hutchinson, S. "Merengue Típico in New York City: A History". Camino Real. Estudios de las Hispanidades Norteamericanas. Alcalá de Henares: Instituto Franklin - UAH, 3:4 (2011): 119-141. Print.

Recibido: 04/02/2011; 2a versión: 06/02/2011. 


\section{Resumen}

Desde los años 60 se ha desarrollado una escena musical transnacional que conecta a Nueva York con Santiago (República Dominicana), a través del merengue típico - un sub-género del merengue tradicional con acordeón (también llamado perico ripiao). Músicos y aficionados residentes en Nueva York han transformado las prácticas musicales, sociales y económicas del típico merengue en ambos lugares, incorporando influencias del hip-hop, reggaetón, rock, house y otros géneros musicales populares internacionales; además de llevar el estilo a nuevos públicos a través de la radio y de representaciones en directo. Este artículo traza la historia del merengue típico en Nueva York a través del testimonio de sus músicos y productores. Al hacerlo, demuestra que los domínico-americanos y los migrantes transnacionales han jugado un papel importante en el desarrollo de este género musical durante casi medio siglo, especialmente en el llamado "merengue con mambo". Aunque este estilo se considera controvertido precisamente por las huellas que han dejado en él los encuentros transnacionales - lo que provoca temor por el futuro del género entre los tradicionalistas - su capacidad de cambio del típico merengue sirve para asegurar su continua vigencia entre las nuevas generaciones.

Palabras clave: domínico-americanos, música tradicional, urbanización, merengue, acordeón, fusión, transnacionalismo, migración, perico ripiao, Cibao, ciudad de Nueva York.

Dominican musicians have lived in New York City since the 1930s. Yet the transnational music scene that exists today, characterized by the constant movement of musicians and exchange of musical ideas, did not begin to develop until well after the first big wave of Dominican migration in the 1960s. In this article, I examine the trajectory of one particular musical genre in this context. Specifically, I outline the history of merengue típico music in New York and the development of New York's transnational tipico scene, and the impact it has had on music and culture in both New York and the Dominican Republic (D.R.).

Merengue tipico is only one of many types of Caribbean merengues (Hutchinson 2010). While the Dominican Republic's is best known internationally, 
even within that country there exist numerous variations, from the recent, controversial merengue de calle or "street merengue" to folk traditions like the merengue redondo of Samaná. Merengue típico, one of the most popular current styles and one of those considered most traditional, is a symbol of traditional rural life as well as an integral part of transnational urban realities. It exists in a state of tension wherein musical changes often correspond to changes in Dominican identity resulting from transnational migration. Both the debates that result and the music itself can thus serve as indicators of current conceptions and contestations of that identity. By turning my attention here to the historical development of tipico in New York City, a story that has not yet been told, I hope to contribute to our understanding of Dominican New Yorkers and the effects they have had on Dominican expressive culture both on and off the island. I also aim to combat nationalistic narratives of merengue history that have refused to consider New York Dominicans as important players in tipico's development.

\section{FIRST STEPS}

The history of orquesta or big-band merengue in the city has been well documented by Paul Austerlitz (1996) and it follows to some extent the history of Dominican immigration to the U.S. As the first Dominicans arrived in New York in the 1930s, Trujillo insisted upon bringing merengue into respectable ballrooms, and so the upscale version of the music made its first appearance in New York at this same time. Damirón and Chapuseaux, Alberto Beltrán, and Rafael Petitón Guzmán ${ }^{1}$ all began playing their literate, orchestrated versions of merengue and other Latin dances in Manhattan during this era.

In contrast to the seventy years of merengue de orquesta in New York, tipico has a comparatively short history in the city. It did not become rooted in the city until the 1970s, much like many of the Dominicans in Brooklyn, Queens, and the Bronx who consume it. Its comparatively late appearance in the city is due to the political and social situation of the time: migration was severely restricted during the rule of Trujillo (19301961), and merengue tipico was in any case then confined to the rural, lower classes that had little opportunity to travel. 
Thus, while one might easily assume that merengue tipico was already present in the Big Apple in the 1950s based on the name of one of the earliest merengue groups there, the impression is false: Angel Viloria y su Conjunto Tipico Cibaeño in fact played only orquesta-style merengues using a piano accordion, much like Luis Alberti in Santiago de los Caballeros. Yet they did begin to disseminate merengue abroad at a time when few island-based groups were permitted to travel, and they were extremely popular in Cuba and Haiti, where their music helped to spawn the new styles of pachanga and konpa (Austerlitz 75). Popular composer Luis Kalaff toured during the same time period, performing some merengues with accordion. But the first traditional tipico musician to have resided in New York may have been Chichito Villa, who spent a few years there in the 1960s. Accordionist for the well-known Trío Seibano, he had played tipico in Puerto Rico, Venezuela, and Colombia, but decided against reforming the trio in the Big Apple (Chaljub 229). He did, however, play at the occasional house party in the 1970s (Díaz).

As mass migration increased after Trujillo's death, the city's landscape changed, as did the musical preferences of the new arrivals. Dominican New Yorkers in the 1960s were mainly Cibaeños, from the northern Dominican Cibao region, and nostalgia and the desire to maintain connections with their homeland drove them to demand live típico. Legendary performers like Tatico Henríquez, El Ciego de Nagua (Bartolo Alvarado), and Fefita la Grande began touring the U.S., simultaneously updating their sound with instruments like congas and electric bass. Talented accordionist Arsenio de la Rosa Caba moved to the Bronx in 1963, and his equally adept brother King de la Rosa followed him there in 1971; both still make their homes in that borough. At that time, these New York-based musicians still played in quartets of accordion, tambora drum, güira scraper, and marimba $a^{2}$ rather than the modernized ensemble of their Santiago counterparts (K. de la Rosa).

Percussionist and music producer Ray "Chinito" Díaz, who grew up on the Lower East Side, remembers that during the 1970s the tipico "scene" in New York consisted mainly of house parties, where his father played tambora with friends. In addition, Ray's brother-in-law played güira with Chichito Villa and gave Ray his first opportunities to perform on the instrument. He notes that his mother always made 
sancocho [stew] for Tatico when he was in town, and has fond memories of his father offering to foot the bill at various tipico gigs: "My father was...parrandero, a partier.That's the way they were. You know, from the campos [countryside]”(Díaz).

Tatico would then play at a club "around the corner," owned by a Puerto Rican couple who were the "big people around the neighborhood." In fact, many Puerto Ricans were involved in tipico at the time, as listeners and even as musicians. For example, King's bass player, Pablo, was Puerto Rican (he is still playing típico; I met him in 2001 when he was performing with Rafaelito Polanco). Another típico site was a small restaurant owned by a Dominican woman from Sabana Iglesia, Ray's father's hometown: "Any musician that came from Dominican Republic would wind up going there, like E1 Ciego, all those people... We all used to get together once in a while and play there" (Díaz). King de la Rosa also recalls Tatico performing at a theater on $14^{\text {th }}$ Street, and notes that accordionist Miguel Santana also moved to the city at that time. However, the audience at the time was more Puerto Rican because "There were very few Dominicans, and there was no one to play for. I'd play a party today and the next, maybe next year."

By the time Díaz became a professional típico musician in the 1980s, just a few small restaurants in Manhattan and Brooklyn featured the music. Around 1984 or 1985, however, dozens of típico clubs appeared all over the city, the focus of activity being first in Brooklyn, then shifting to Manhattan and the Bronx in the early 1990s, and then back to Brooklyn again. Atlantic and Fulton Avenues in East New York had the greatest concentration, with clubs like Continental and Astromundo. But Sunset Park, where Ray's family moved after leaving the Lower East Side during his elementary school years, also had many clubs. These included the Golden Fish at Fifth Avenue and $18^{\text {th }}$ Street, Woody Catering Hall at Fifth and $56^{\text {th }}$, and El Flamingo on $62^{\text {nd }}$ and Sixth or Seventh Avenue. Williamsburg's Southside was home to the Vista Mar, where Ray played weekly with King de la Rosa for years (Díaz). Live típico can still be found in each of these neighborhoods.

\section{TIPICO GROWS ROOTS IN THE CITY}

Transnational practices linking Santiago with New York became more commonplace, and this affected the music. Tipico's moment of transnationalization is 
exemplified by the King de la Rosa LP titled Merengue Ripiao (Amor Records, ca. 1981). The cover shows the band members posed on a Lower East Side street in matching jumpsuits. King, with fashionable Afro hairdo, is surrounded by Pablo, the Puerto Rican bass player; Purito, a tamborero who has traveled constantly back and forth between New York and Santiago for four decades; and Ray Díaz of the Lower East Side. The album became a huge hit back in Santiago — probably the first típico recording from New York to do so - and led to a major Dominican tour for the group, where the group played daily for three months (Díaz). However, although the recording sold well, King made little money from it, regarding it instead as a promotional tool: "Always, the one who produces it is the one who gets the most benefit from it."

Díaz recalls this tour fondly, along with the unique innovations he and the group then made. Dominican audiences were particularly impressed, unable to believe "un americano" could play güira for típico, notoriously difficult with its fast tempos and complex rhythms. Chinito became known both for speed and for his antics while playing, some of which were also directly due to his New York upbringing. Few who saw him play on that tour, at age sixteen, have forgotten the experience. He explains that in the 1970s, he and his friends formed a roller skating "crew" called the Manhattan Rollers, which would skate around Washington Square Park wearing matching sweatshirts featuring the crew name, individual name, and horoscope sign.

I was the kind of skater that I wasn't afraid of anything. Going downstairs, going behind cars holding on from the back, doing flips into splits, I wasn't afraid. I think this is the way it happened... At that time I was already playing with King, he used to play in the Vista Mar, which is in Los Sures, the southside, Brooklyn... We used to play there every Friday and Sundays. So what I used to do is, since I lived on the Lower East Side, I used to cross the Williamsburg Bridge on skates. And I used to go and then go into the fiesta in my skates. (Díaz)

Purito, the tamborero, saw the way he skated and suggested he bring them to the Dominican Republic. Díaz took the suggestion.

I used to take a solo on the güira while I was dancing with the skates. You know, doing just regular moves, you know, regular dancing moves, and then, I didn't do the flip there but I did - I used to do like a roll with the güira. Not a roll, it was more like a shh, shhhhhhhh [imitates a drawn-out güira stroke], 
like that. I would stay there for a bit. While I was doing that, I would go into a split. You know, smoothly go down, and then like this pick myself up by the back [of my shirt].Then I used to go on the floor - while playing güira. That became so popular that the first thing people would ask us, or ask me [was], "did you bring the skates?" (Díaz)

This kind of showmanship was one reason for the group's success both in the D.R. and in New York. Another was that when Chinito started playing and recording with King in the late 1970s, New York's style of merengue tipico was different from that of the D.R. For instance, one of the group's first binational successes was "El Giro y el Canelo" (The black-and-yellow and the white-and-red rooster), a traditional piece that at first might seem an unlikely hit. Díaz attributes the success not only to King's famous accordion solo, but also to "the arrangement of the song, you know, with the saxophone solo, which was actually [played by] 'Mollejita'," and particularly to Purito's cortes. Cortes are moments in which the tambora, güira, and bass play a syncopated riff together, momentarily breaking the flow of the merengue rhythm; they may be prearranged or created in the moment. And while El Ciego's Santiago-based group was also very creative and played some simple cortes at the time, Díaz still thinks that "Even today, everything comes from here, from New York... All the inventions, all the new stuff, all the creativity - all the craziness, I'm gonna say - comes from New York." One example he cites is the recent addition of timbales to the tamborero's set-up, a ubiquitous feature of today's merengue con mambo. Díaz first started with a snare, then switched over to timbales in 1994, and he explains this as a result of New York's diverse musical environment: “ [It came from] me being around a lot of different music, playing Latin jazz, playing disco, playing típico... Just going to concerts, looking at or buying music" (Díaz).

\section{INVISIBLE FUSIONS}

Chinito's vibrant, ultra-syncopated and improvisatory güira playing made a huge splash, and many young güira players today emulate his style, although they are unaware of its origins. In fact, it was Diaz's experiences in early hip-hop on the Lower East Side that added another dimension to his güira playing and, he believes, inspired him to experiment with new rhythms and sounds: 
I was into the deejay thing too... I started out with two turntables, a little mixer, you know, and one speaker, and I was already doing scratches. You know, scratches, like hip-hop: chick-a-chick-a-chick-chick! So... I started, you know, transferring that, or taking that to the güira... One of the things why I became looked at, or I guess popular, with the güira, was that I was doing a lot of syncopation stuff... Things like that, nobody was doing that. So I got that by playing around, trying to be a deejay... And maybe it was just looking at and listening to other music, you know? I was brought up in a crazy music environment. My brothers used to listen to rock or disco, and we listened to merengue típico from my father. So I guess... all those things started going into your brain or something... so you start putting all those things together and next thing you know, you're starting to create other stuff. (Díaz)

Most D.R.-based musicians do not know this sound is a New York import, even though they often imitate it.

The lively style of King's group carried forward through the efforts of other New York-based musicians, such as accordionist Toribio de la Cruz, the first artist ever to be sponsored by impresario Aureliano Guzmán, who plays a central role in the contemporary tipico business. Guzmán remembers becoming interested in merengue tipico after moving to the city in 1977 and attending some gigs played by accordionist María Díaz. In the mid-eighties he was introduced to Toribio at a friend's house party. Impressed by his playing and friendly personality, Aureliano took the accordionist under his wing, connecting him with tamborero Boca Chula and Ramoncito Güira when told he needed help purchasing equipment and starting a group. "That was a group with all the stars of the time.... In 1986, that was the group that had the greatest impact" (Guzmán).

The impact made by the group's album, El Contentoso, was doubtless caused by their energetic sound created with breakneck tempi; the incredible virtuosity of every group member, including saxophonist José el Calvo and the highly-regarded vocalist Vinicio López; innovative arrangements; and driving rhythms on tambora, güira, and bass. Tamborero Boca Chula's special feel for the traditional pambiche rhythm infused the album, as it accounted for half of the tracks recorded. Meanwhile, Boca Chula and güirero Ramoncito continued the practice they had earlier started when playing with María Díaz of creating inventive cortes (though they explain they borrowed this idea 
from merengue de orquesta, not New York típico; Jiménez, R. de la Rosa). While most of the songs were traditional, not original, the group's arrangements made the old merengue sound fresh, as did Toribio's stellar technique which, in "La Pobre Adela," even underlies the vocals (traditionally, the accordionist would have stopped playing during the singing, only filling in between lines). It is no surprise that this album is still popular today.

\section{THE BIRTH OF MERENGUE CON MAMBO}

The next landmark recording came out only a year later: Agapito Pascual's 1987 single, "La Vieja y Su Pipa" (The Old Woman and Her Pipe). While not a New Yorkbased musician, Agapito's arrangement was heavily influenced by New York styles and even included a section of scratching. It is because of this record that many consider Agapito Pascual the creator of merengue con mambo, a style which caught on like wildfire in New York and, later, in Santiago; he might even be considered to be the progenitor of the so-called "super-modern" style later propagated by groups like Aguakate. Mambos are the short, catchy riffs played by accordion and saxophone in the second part of the merengue, and Agapito himself traces the development of today's mambo-based tipico groups directly to this song: "That's the song that has taken me to where I am today. Krisspy began to eat [i.e. to make money] with that... [In tipico], we always take a song [from others] and record it" (A. Pascual). As he explains, however, even modern tipico functions through the traditional method of making new variations on older songs.

Agapito's mambo-heavy merengue típico had many detractors, even though it was largely responsible for the resurgence of interest in the genre. He was nicknamed "E1 Moderno" (the Modern One) by record label owner José Luis (Austerlitz 364), but Agapito himself sees his music as a compromise between the traditional and the modern: "People said to me that my music was 'crazy' because they don't like the musical style... I do like it, because I come from that; but I also like the traditional style, because I also come from that" (A. Pascual).

After a successful tour of New York City in 1989, Agapito was given a hero's welcome upon his return to Santiago. Domingo Arias recalls, "When Agapito would 
come back from New York, the people would receive him with caravans at the dry bridge" (Arias). "Dry bridge" or puente seco refers to a pedestrian bridge over the SantiagoNavarrete highway, located near two well-known típico clubs, "Rancho Merengue" and "La Tinaja". The bridge is known to típico fans as the site where Isaías "Saco" Henríquez, Tatico's brother and güirero, was either killed or committed suicide. While the mystery is still unsolved, the event is commemorated in a still-popular merengue, "El Puente Seco" by the late Diógenes Jiménez. Rhetorically tying Agapito's music to that historic location illustrated the new style's successful conquest of young Cibaeño audiences as well as the linkage tipico moderno provided between Santiago and New York.

Many new tipico groups sprouted up in the 1990s in response to increasing demand, both from new immigrants interested in old-time music and from established New York Dominicans wanting to hear the new style. The divide between "traditional" and "modern" styles grew concurrently with the shift from house parties to restaurants and clubs. Tipico musicians back on the island heard of the growth in the New York City scene, and, because demand was high and few tipico groups were then living in the U.S., immigrated to eastern Brooklyn neighborhoods in the early- to mid-1990s. At that time, peripheral communities like these offered more affordable housing than Washington Heights as well as a sense of community with other musicians; musicians also saw the area as more tranquil and less troublesome than Upper Manhattan, where drug-related crime and gang activity was high. As part of a new wave of lower-class immigration, tipico musicians contributed to the growth of these neighborhoods far from the more established (and more researched) centers of Dominican immigrant life. Thus, when I began to research tipico in 2001, I found numerous full-time tipico musicians living within a radius of just a few blocks in East New York.

\section{THE TÍPICO EXPLOSION}

Brooklyn-and Queens-based tipico groups proliferated through the 1990s. These included those led by young accordionists like David Polanco, who uses the artistic name David David (in New York 1993-2001), Lidia de la Rosa (in New York since 1989) ${ }^{3}$, and Rafaelito Polanco (in New York 1994-2007); saxophonist El Chivo; 
members of the old guard like Ernestidio Rodríguez (in East New York since 1990) and Berto Reyes (still in Corona, Queens); and young groups like "Super Mambo Típico" and "Grupo Burla", all perpetually forming, reforming, dissolving, and changing membership. In Manhattan, Ricardo Gutiérrez released some popular recordings in the new style, while his older brother Nicolás Gutiérrez, "Mano Bruja" ("Witchy Hand"), continued playing traditional tipico from his home base in the Bronx, where Arsenio and King de la Rosa were also still active. David David and Lidia de la Rosa experimented with novel arrangements and instrumentation, including piano on some recordings. Lidia and Berto both recorded numbers featuring rap vocals, Berto's homage to the World Trade Center penned by bass player Santo Gil. At a gig in Queens in 2002, I even saw Berto invite a U.S.-born teenage rapper in the audience to improvise with the group, as would traditionally be done with any visiting típico instrumentalist.

David David deserves some credit for the growth and development of the merengue con mambo style after Agapito's initial foray. He moved to New York in 1993 on a tour organized by José Tejeda, recorded four albums under Aureliano Guzmán, then self-produced another. Yet times were still difficult for tipico musicians. About playing in Sunset Park restaurants, he notes, "There were very good parties there... and there were also some gunfights. Police going after drug traffickers, they'd get off some shots while one was playing there. Oh, it was full of that" (Polanco).

Besides such living situations, attitudes were also problematic: "Young people did not want to get into traditional music, because they said they'd be compared to peasants - which is [really] something to be proud of; so I said, I'm going to change the music a bit"(Polanco). David credits part of his success to simply having a bigger, better sound system than other tipico groups of the time, but his short, catchy mambos and polished vocals also set the standard for all the young groups that came after; he also experimented with the inclusion of keyboards and romantic, balada-influenced compositions that proved to be popular.

Meanwhile, Lidia de la Rosa and her ex-husband and producer, Ray Díaz, were also innovating within the genre: both of them played tipico instruments with Mario Rivera's merengue-jazz group on occasion, and their collaborative recordings included 
fusions with palos rhythms (in "Volvî" and "Mi Tierra"), bachata and merengue de orquesta (“Mi Jardín”), and reggaetón-style rapping ("Prepárate Bien”; all on the album $L a$ Muñequita, 2001). However, their music was perhaps too innovative for mainstream Dominican tastes, and it did not have the success of David's early recordings.

\section{FULANITO'S FUSIONS}

In 1997, a major change for tipico came along with the advent of group Fulanito and the release of their album, "E1 Hombre Más Famoso de la Tierra." (The word fulano is a generic name for an unknown person, similar to "John Doe;" the album's title, "The Most Famous Man on Earth," is a joke based on that fact. ${ }^{4}$ ) Fronted by rappers Rafael Vargas and Winston de la Rosa, the group was the first to fuse the beat of merenhouse music and rap vocals with tipico accordion playing. The combination proved to be phenomenally successful.

The story of Fulanito provides a good example of how some New York Dominicans relate to típico, as well as the obstacles that music faces in gaining an urban audience. One of the group's founders, Winston, was heir to a tipico accordion dynasty that stretched from his grandfather, Yan de la Rosa, composer of "La Rubia y Yo;" through his father Arsenio and his uncle King, down to his cousin, Lidia. None of Arsenio's or King's New York-born children played típico or listened to it — instead, they grew up surrounded by the South Bronx's nascent hip-hop culture. They did, however, inherit musical talents and affinities, and several went on to make hip-hop music. Winston and his eldest brother Joe became sound engineers, even getting to know Afrika Bambaataa and Jazzy J through their work, while Joe is also a producer and a keyboard player who worked on Fulanito's later efforts. The other of the group's founders, Rafael Vargas, was a rapper who already had some hits under his belt. Vargas met Winston in the studio, and was excited to find he had a Dominican sound engineer. The two soon partnered up to form the hip-hop duo 2 in a Room, which had a hit with the club song "Wiggle It," and later the 740 Boys. Then they hit upon the idea of combining merengue with rap, and created Fulanito (J. de la Rosa).

Joe recalls the moment in which the group's sound was born as a result of some old DAT tapes found lying around Winston's studio: 
We put on King's stuff first and the first song that came on was... "Si Mateo Se Muere"...That song came on and we were like, "Whoa, this is pretty good!" and it was like all my cousins and all my brothers, like ten of us, and we're just hanging in my brother's studio, and we listen to this stuff for the first time since we were five, six years old... We stopped the session. The whole night we just listened to King and my father. Perico ripiao. You know, nobody ever played that stuff, other than when we were kids, and we just started getting into it, and we were like, "Man, listen, this is off the hook!"We started playing it, and we started playing tambora and güira, and I grabbed the accordion... I started mimicking... "La Chiflera". (J. de la Rosa)

Although they had hated the music as children, as they matured they found they could appreciate their father's and uncle's musicianship. It was natural, then, for them to invite Arsenio and King to record accordion tracks for their project. The 1997 hit "Guallando" overlaid rap vocals by Rafael Vargas with Arsenio's performance of the accordion theme from the 1970s tipico hit by Arístides Ramírez, "La Chiflera."Joe explains, "Back in the late '90s, anything you rap, you put rap on it, it just worked."

Yet the group first had to overcome a musical problem. Joe continues, "Perico ripiao is like 160,170 BPMs and hip hop is like 95, 90.”Therefore, they decided to keep the merengue beat, and rap over that. Once this problem was resolved, the group created a one-bar rhythmic loop and recorded Arsenio playing an incredibly difficult and fast accordion riff over that. Next, they altered the rhythm, added breaks, and corrected accordion notes:

We went note by note, and whenever we heard an error, "oh, just move this here" - or sometimes he would play a wrong note and I would pitch it up or pitch it down to where it would be the right note... So if you listen to "Guallando," there's no errors at all. (J. de la Rosa)

Today, however, Joe thinks this approach makes the song sound too "digital." In his current productions, he instead moves notes so that they fall slightly ahead of or behind the beat, thus sounding "live, not so computerized" (J. de la Rosa).

There were also cultural obstacles to overcome. Rafael Vargas explains:

The other [merengue/hip-hop hybrid] groups, like Proyecto Uno, Sandy y Papo and Ilegales, they were doing it with more of a big-band [orquesta] merengue. But I was like, let's try and go even farther back to the thing that started the whole thing off. And that was the accordion, what they used to 
play up there in the mountains. People really dig that - when you play perico ripiao people just go bananas, but it was more of an underground thing. It's the typical folk music of the Dominican Republic, and no one [on the popular music scene] was touching that stuff with a ten-foot pole. (Wald)

Vargas clearly recognized the symbolic power merengue tipico wields among Dominican transmigrants, and thus decided to defy the conventions that continue to keep the style from reaching a broader audience. While the group was not immediately accepted - Joe says his cousins felt the two styles were like "oil and water" - the idea eventually caught on, leading to extensive tours on which Arsenio accompanied the group; it was so popular in the D.R. that they “couldn't walk the streets" when they toured the country because of the swarms of fans (J. de la Rosa).

\section{TÍPICO SELLS}

Although Fulanito is not a tipico group, they brought the tipico accordion to a wider audience and opened the door for future innovations. Just two years later, New York-based accordionist Robert Vargas worked with businessman José Mateo, better known as "Peligro", to create what may be típico's all-time biggest seller, the CD Dando Pela y Desafiando a Cualquiera (Putting Up a Fight and Challenging Anyone) and its controversial hit single, "El Moñoñón” (a term for female genitalia). The group included several long-time New York residents, such as Diógenes Bonilla "El Original" on saxophone, Guillermo “Tano” Brisita (who played with Francisco Ulloa on Juan Luis Guerra's 1994 album Fogaraté) on bass, and Eddy Tambora, each putting their distinctive stamp on the recording. Featuring a clean, crisp sound different from the lush feel of 1980s recordings like Toribio's, the album highlighted the syncopated, staccato rhythms of the mambos as well as the dirty yet catchy lyrics penned mainly by Vargas.

Robert and Peligro deliberately created this style to appeal to a broad range of Dominican New Yorkers. It had an urban, working-class sensibility while still catering to Cibaeños' nostalgia and need for ties with their homeland. Peligro himself shared many experiences with the group's audience. He remembers that when he arrived in the city, tipico was far from cool, and coworkers mocked it as "country" music: 
When I closed up [shop] and was going to mop the floor I would turn it on, play my merengue [...] If I put it on when people were there, they would say to me, "turn that off, play me something else," because, you know, it wasn't their style. But little by little tipico has gained a bit of territory. (Mateo)

The same might be said of Peligro himself, who began by working in a Dunkin' Donuts shop downtown but never turned down an opportunity. In this way he went on to first own a sandwich shop, then a record shop, and there he had the idea of forming a tipico group. The style was already fairly popular, he recalled, with José el Calvo's being among the top groups. But he saw an opportunity with the young, New York-based Robert Vargas, who had both drive and a different flavor to his music.

I told him, "Robert, the people and the deejays want [...] something that will be different, new." Because in whatever disco or restaurant you go to, they mix the music up for you and they'll put on two merengues tipicos, but they'll always play "Diente de Oro" or one of those old merengues[....] But you could hear that the deejays had a thirst to play some tipico. (Mateo)

In 1996 they put a group together and began to play in restaurants, and a year later, they recorded the group's first CD. It was a bit of a gamble, Peligro recalls, since the style was so different from contemporary groups:

I presented it to all those record labels, but no one was interested. So I said, okay, let me release it myself. I ordered the manufacture of the CDs and began to sell them here with friends[....] [It was] a very catchy album, very different from what [others] were doing, so I was much criticized because it was something different, something very plebian. It was totally different from what had been consumed before in típico. (Mateo)

It didn't take long, however, for the Vargas style to catch on with listeners. The CD was a surprise hit. Peligro printed the first five thousand copies himself and sold out in three weeks, going on to work with the label then producing Fulanito. With them, the single "El Moñoñón” got airplay on Caliente FM (today's Latino Mix) and La Mega. After that, Peligro remembers picking up 10,000 more copies from the label and selling out in one day to all the record stores along Tenth Avenue in Manhattan, such as Rincón Musical, Manhattan Records, and Juan y Nelson. The album was a hit abroad, as well, and the group even received invitations to perform in Colombia (which they turned down because of safety concerns). 
To my knowledge, no other production in the genre has matched Vargas's sales figures, which, according to Peligro, reached 65,000 copies. Before that, LPs and then CDs sold only in the hundreds or low thousands: "Geovanny and El Prodigio sold, but they could not get beyond 10,000 and 15,000 because piracy was already high when they began. So I had the opportunity, since when we came out piracy was there but not with the strength it has today" (Mateo). The CD apparently opened the door for others, since after that, Peligro remembers, other stars of modern tipico began to emerge in Santiago: El Prodigio, Geovanny Polanco, Krisspy. Yet the tug-of-war between "traditional" and "modern" styles both on and off the island was constant. Fidelina Pascual, Agapito's sister and a modern-style accordionist herself, recalls arriving in New York and forming a group in 1997. When she tried playing her mambo-driven music in Santiago in 1999, the audience was "not ready". But upon returning in late 2002, she found that styles had changed: "Here [in Santiago] people were more prepared - a new youth. Or rather, now those people were gone who really blocked the genres, or not the genres but the new musicians...The old fans had blocked us" (F. Pascual).

\section{URBANIZING TÍPICO}

As a "roots" music with a limited audience, típico has for the most part stayed within the bounds of its genre and played to Dominicans (although Colombians, Mexicans, Ecuadorans, and Puerto Ricans also attend shows). Yet given all the contact New York típico musicians have with other musical genres and ethnic groups, some do attempt to create musical fusions. Most such experiments have been unsuccessful in gaining crossover audiences, or indeed attracting much interest from the core group of tipico fans. The few exceptions to this rule arose in New York through contact with hiphop culture. I have already noted the case of Fulanito. As Fulanito's later albums became progressively less accordion-based, the group Aguakate (in existence 2003-2007) picked up where they left off.

Aguakate's music is more explicitly tipico-based than Fulanito's, which only made it a greater target for traditional fans'vitriol. During my research in New York and Santiago, the group was frequently accused of distorting tipico's rhythms, creating 
immoral lyrics, and generally being a bad influence on youth. But because I knew many of the musicians involved before Aguakate was formed, I was able to watch the group's development from beginning to end, observing some of their creative and decisionmaking processes, which allowed me to see how their trajectory related to simultaneous developments in tipico and Dominican society.

Aguakate was another creation of Peligro, in cooperation with lead vocalist "Chino", then a radio personality on La Mega, New York's biggest Latino radio station. Chino later changed the spelling of his name to "Shino", perhaps (like that " $k$ " in Aguakate) a nod to the North American environment since there is no "sh" in Spanish. While Aguakate's style was far different from Vargas's, it owed much to his work. Peligro explains that today, "You have to have very urban material... The problem now in tipico is that the majority of groups have just kept making merengues for their fans, and they don't make merengues to be commercialized." Thus, he believes that even talented modern accordionists like E1 Prodigio follow the path of least resistance, eventually abandoning innovation in favor of the classics.

Peligro did not want his group to be caught in the trap of playing only a traditional repertoire, and thus performing only for longtime tipico fans. Instead, they wanted to create a unique sound to attract a different audience. Peligro explains Aguakate's concept:

We have had an audience none of the other groups have been able to reach. You know, alongside a Puff Daddy on stage, a Busta Rhymes. Also... we have gone many times to the Copacabana. You know, these are sites that never opened their doors [to tipico] and we have played many times ... out there, in Chicago, in Maryland, and other places... [It is] something different that other people who are not Dominican can consume. For example, there are the Puerto Ricans, the Salvadorans... Sometimes tipico needs - if you have to mix it with another rhythm, you do it so that tipico will be strong. If you mix it with another rhythm, that's when I think it can reach other people. (Mateo)

The intuition proved to be correct, since Aguakate's first CD, though plagued by piracy, sold about 22,000 copies by Peligro's estimate, while their second, released by Universal, sold 20,000 in advance sales alone.

In the early months of 2003, I sat in as Aguakate rehearsed in a basement studio in Washington Heights, and later, as they recorded their first album. It was not easy to 
put this group together, simply because, while others wanted to play only to traditional tipico fans, Aguakate wanted to play for everyone and to create something new. There were difficulties in finding appropriate instrumentalists. For example, some musicians complained that the tamborero tuned his instrument too low, giving the music an antiquated sound that contrasted with the high-pitched tamboras used by most modern groups. Eventually, another tamborero was found.

Finding an accordionist was even more difficult. When the recording began, the group still had no permanent accordionist, as none could satisfy all their requirements. One young man joined for only a month or two. While he easily learned the group's new compositions, they worried that he did not know enough of the traditional repertoire to satisfy audience requests and that tipico fans would therefore not take the group seriously. After he was rejected, another accordionist was invited, one who was popular with the viejetes or old-school fans for his interpretations of traditional merengues. Yet when the group went to the recording studio, it was discovered that he could not play the crisp staccato rhythms of the mambos in sync with the saxophone. Too much time would have been wasted in making their articulations match, so he too was rejected. Finally, a replacement was found in Belarminio Liriano, a Cibaeño from a musical family who had immigrated to New York in 1993. He had played with Brisita and Bonilla in an earlier group, and the previous year had told me that he wanted "to create many new things, many mambos. To try to bring it to the people, to everyone, to the youth, to the children, to adults, everyone. That they should enjoy hearing the music, to market it, so that progress will continue". His ideas of "progress" matched with the Aguakate project, and that of so-called "super-modern" tipico in general (a term used by fans, radio announcers, and the groups themselves).

When completed, the CD's introduction made clear the group's intention of introducing listeners to new styles of music and creating something innovative within a tipico framework. The first sound effects on De Otra Galaxia (From Another Galaxy) depict a spaceship, and announcements tell us we are headed for collision with an "Aguakateroide" (Avocaderoid). On realizing the ship is entering another galaxy, the captain shouts for Sergeant Tambora to activate the "mambómetro" (mambo-meter), 
and thus are we launched into the Aguakate galaxy. After this, the album consists mainly of original songs in tipico moderno style, many of them penned by Shino with his trademark punning and double-entendre lyrics, though with numerous tongue-in-cheek musical quotes like the Woody Woodpecker opening to "E1 Pájaro Loco" “The Crazy Bird," the Spanish term for Woody Woodpecker). The most innovative piece was "Reggaetón Ripiao," which alternated between the electronic beats typical of reggaetón and a tambora playing the same rhythm. In live performances, Aguakate went even further, quoting from five or more styles of music in one night. For example, in a live recording made in Puerto Plata, Dominican Republic, they borrowed a few lines from a rock song by Colombian star Juanes, a pop merengue by Toño Rosario, a Tego Calderón reggaetón, a Joe Veras bachata, and even "Eye of the Tiger".

Aguakate's musical manipulations were met with some resistance, but their lyrics and stage behavior were even more controversial. Some of Shino's improvised asides, such as a controversial statement about baseball player Alex Rodríguez being a "race denier" in 2004 performances of the song "Usted se lo pierde" ("You're missing out;" Hutchinson 2008), stirred up rancorous debates over the differences between island- and US-based Dominican identities. Some listeners agreed with A-Rod's assertion that because he grew up in the US, he was American, while others sided with Shino, accusing him of hiding his roots. One internet user even used music as a litmus test for ethnicity, stating, "Yo, what Alex is is an [expletive]... Just because you're born in New York doesn't mean you are a gringo. How the hell does he know Spanish if he's not Dominican? Ask him what he listened to when he was a kid - merengue or rock and roll??" (Remo; my translation).

From the beginning, Aguakate was advertised as "el grupo más loco" or "the craziest group." The term "crazy" referred to everything from their musical fusions to offensive language, hip-hop-influenced clothing styles, and Afro-centric hairstyles. Their second album, whose cover pictured a red-tinted, upside-down Shino with teased-out Afro, was even titled Crazyssimo. Although listeners used the word with both positive and negative intention, the band embraced it. The use of the term also recalls Agapito Pascual's statement about people's reactions to his "crazy" 1980s merengue con mambo. 
The choice of the term "crazy" is significant. Jazz scholar George Lewis explains that African American be-bop musicians were called "crazy" because the term was "often assigned to oppositional forces, either by the dominant order itself or by members of an oppressed group who, however onerous their present situation, are fearful of the consequences of change" (Lewis 95). Similarly, Shino represents opposition to typical Dominican beliefs about African heritage, most obviously through his hairstyles, and about Dominican Yorks, through his staged comments about identity. The group as a whole, through its combination of symbolically powerful tipico music with morallysuspect foreign genres like reggaetón, likewise represents opposition to dominant Dominican ideas about traditional culture and change. As Jorge Duany describes for Puerto Ricans, one's choice of music can "represent where one stands on the acculturation/resistance spectrum" (201), so that choosing salsa may symbolize "resistance to the loss of national identity, whether through the migration experience or the cultural penetration of the island" (Duany 199). Merengue típico serves a similar function for Dominicans. Therefore, Aguakate's mixture of tipico with foreign rhythms is symbolically perplexing, confusing - and "crazy."

\section{CONCLUSIONS}

Tipico has long been nationalized, considered a national symbol in spite of its plainly regional identification. In New York, it has become internationalized by virtue of being played in two different countries and consumed by several nationalities. More importantly, however, it has become transnationalized by virtue of its constant movement, both literal and figurative, between New York and Santiago.

Evidence of tipico's transnationalism can be found in numerous aspects of the music's performance, from its contexts, production networks, and economic structures, to musicians' clothing and behavior to actual musical features like lyrics, rhythms, and melodies (Hutchinson 2006). Each may become the site of dispute between those who support "modern" or "traditional" típico styles, a polarity that can also be read as a debate over how much transnationalism and foreign influence should be allowed within Dominican culture. By examining the choices musicians make and the ways in which 
Dominican New Yorkers combine two cultures, one can see the process not as one of cultural loss, as many island-based Dominicans would have it, but as one of strategic adaptation, diversification, and even enrichment. Nevertheless, these choices place "traditional" and "modern" musicians and listeners in a continual tug-of-war.

The battle lines between places and styles are not as clearly drawn as one might assume Fulanito and Aguakate in a sense represent the expected: the experience of immigration and urbanization resulting in the innovative adoption of some aspects of "foreign" genres. The choices the groups made are emblematic of classic anthropological ideas of acculturation. As David David states:

New York is to blame for the evolution of merengue tipico, because there all musical genres come together. So over there people tire quickly of things, and you have to evolve in accordance with the city; that's what it's about. So when a group is established in the United States, you have to focus yourself in accordance with the environment, and whoever travels there always has to keep themselves on top of the fashions. That's what it's about: that is how New York has influenced muisica tipica. (Polanco)

But tipico in New York is not so simple, because in spite of all the experimentation, the dominant style of merengue played in the city is actually the most traditional. King de la Rosa explains, "Merengue tipico here is better than tipico over there [on the island], such as the quartet merengue. Now the [large] group merengue is fine, the one from over there is nicer like that, young people are liking it like that; but merengue is being played in a more true way here in New York, since here one plays more quartets than anything" (K. de la Rosa). The reason is partly economic, since quartets are more affordable for the small restaurants in which típico is usually played in the city. It is also emotional, since tipico can serve a nostalgic function.

The paradox of New York tipico - namely, that it can simultaneously be more conservative and more progressive than island-based tipico - shows the complexity of diasporic expressive culture. The changes that New York-based and transnational tipico musicians made in their music have affected all aspects of how the style is produced and consumed, both in Santiago and New York. At the same time, the maintenance of traditional ways of playing is sometimes heightened - and not only by nostalgic immigrants, but also by New York-born Dominican Americans. For instance, 
accordionist Genito of the group Geniswing grew up on the Lower East Side with no accordion teacher. Instead, he used a computer program to slow down 1960s-70s recordings by Tatico Henríquez, learning each merengue note for note. Thus, the most perfect reproduction of Tatico's playing yet may have been made by a New Yorker aided by the latest technology.

Modern merengue típico is controversial precisely because it shows the impact of urbanization and transnational migration on expressive culture in its divergence from traditional values; its combination of different economic systems; and its incorporation of new rhythms, instruments, and clothing styles. Meanwhile, the traditional quartet style is more popular than ever, but remains largely invisible to outsiders. Thus, although tipico is still perceived as the most traditional of Dominican popular musical genres, it continues to change with the times, incorporating new sounds, new gender roles, new generations with different experiences. If it did not, típico could only be typical of a campo that no longer exists; instead, it is the perfect emblem for Cibaeños in the ciudad.

\section{REFERENCES}

Arias, D. Personal interview. 18 July 2004.

Austerlitz, P. Merengue: Dominican music and Dominican identity. Philadelphia: Temple University Press, 1996. Print.

Chaljub Mejía, R. Antes de que te vayas ... trayectoria del merengue folclórico. [Santiago, D.R.]: Grupo León Jimenes, 2002. Print.

de la Rosa, J. Personal interview. 21 August 2006.

de la Rosa, K. Personal interview. 26 June 2006.

de la Rosa Arias, R. O. Telephone interview. 12 June 2007.

Díaz, R. Personal interview. 1 July 2006.

Duany, J. "Popular music in Puerto Rico: Toward an anthropology of salsa". Latin American Music Review 5:2 (1984): 186-214. Print.

Guzmán, A. Personal interview. 25 May 2006.

Hutchinson, S. "Merengue típico: Transnational regionalism and class transformations in a neotraditional Dominican music". Ethnomusicology 50:1 (2006): 37-72. Print. 
. Merengue tipico in transnational Dominican communities: Gender, geography, migration, and memory in a traditional music. Ph.D. dissertation, New York University, 2008. Print.

. "Los merengues caribeños: Naciones rítmicas en el mar de la música". In $A$ tres bandas. Mestizaje, sincretismo e hibridación en el espacio sonoro hispanoamericano (s. $X V I-s . X X)$. Madrid: Sociedad Estatal para la Acción Cultural Exterior (SEACEX), 2010. Print.

Jiménez, R. Telephone interview. 12 June 2007.

Lewis, G. E. "Improvised music after 1950: Afrological and Eurological perspectives". Black Music Research Journal 16:1 (1996): 91-122. Print.

Mateo, J. Personal interview. 19 July 2006.

Pascual, A. Personal interview. 2 July 2004.

Pascual, F. Personal interview. 9 July 2004.

Polanco, D. Personal interview. 24 February 2006.

Remo. Comments in response to "MP3 Usted Se Lo Pierde". Remolacha.com 4-17 November 2004. Web. 3 July 2006.

Wald, Elijah. "Fulanito”. Elijabwald.com 1999. Web. 24 May 2007.

\section{NOTES}

${ }^{1}$ Petitón Guzmán was among the first Dominican bandleaders in New York. His orquesta performed Julio Alberto Hernández's merengue "Caminito de mi casa" at Radio City Music Hall in 1939 (Santiago 1985). Because his studies at Julliard were financed by Trujillo, Petitón was the victim of attacks after the dictator's death that resulted in most of his music being lost. The family donated the composer's manuscripts to CUNY's Dominican Studies Institute (DSI) and they were the subject of a 2008 research project by the author, supported by a DSI summer research scholarship.

${ }^{2}$ Marimba is a bass lamellophone that looks like an oversized thumb piano (marimbula in Cuba); it is sat upon as it is played. Today it has been replaced by electric bass.

${ }^{3}$ See Hutchinson 2008a.

${ }^{4}$ I was distressed when, after writing an encyclopedia article on merengue, I discovered the editors had added several sentences to my article without permission or consultation. The addition expressed the view that Fulanito's name was derived from Fulani, the African tribe. While the etymology of the word may be correct, the information in this context was irrelevant, since it was chosen to be humorous, not to make any kind of political statement about race (as the album title makes clear).

5 “The Golden Tooth" by El Ciego de Nagua. 